\title{
Pengaruh Interval Pemotongan Rumput Brachiaria humidicola (Rendle) Schweick terhadap Konsentrasi Amonia dan Asam Lemak Terbang (In Vitro)
}

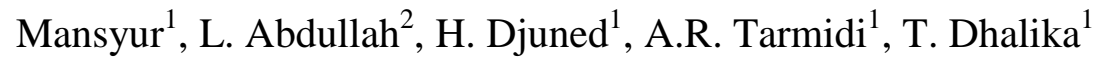 \\ ${ }^{1}$ Fakultas Peternakan Universitas Padjadjaran, Bandung \\ ${ }^{2}$ Fakultas Peternakan Institut Pertanian Bogor
}

\begin{abstract}
The existence of weeds significantly depressed productivity and quality of herbage. Physically weed controlled by defoliation could be expected to sustain quality and production of herbage, and able to control weeds expansion. The aims of study were to find the effect of interval defoliations of $B$. humidicola that invited by $C$. odorata and its effect on concentration of ammonia and volatile fatty acid of B. humidicola herbage (in vitro). The experiment was carried out at Laboratory of Agrostology, Faculty of Animal Science Bogor Agricultural University. In vitro digestibility of herbage was analyzed at Ruminant Nutrition and Feed Chemistry Laboratory, Faculty of Animal Husbandry, Padjadjaran University. Split plot design in time was used in the field experiment. The treatments were nine different planting methods and different defoliation intervals. Defoliation times are divided on the first defoliation and the last defoliation. The results showed that concentration of both ammonia and volatile fatty acid of herbage, which defoliated every 60 days were found significantly higher than those defoliated every 30 days and 90 days. Present and defoliation of $C$. odorata didn't give significant effect on the concentration of ammonia and volatile fatty acid of $B$. humidicola herbage.
\end{abstract}

Key words: ammonia, volatile fatty acid, herbage, defoliation interval, in vitro

\section{Pendahuluan}

Pada beberapa kasus padang penggembalaan di Indonesia telah banyak diinvasi oleh beberapa jenis gulma. Salah satunya Chromolaena odorata. Padang penggembalaan yang terinvasi oleh gulma menyebabkan terjadinya penurunan produksi dan kualitas padang penggembalaan. Keadaan tersebut akan merugikan usaha peternakan karena ternak tidak memperoleh makanan yang cukup dari padang penggembalaan. Bamualim et al. (1990) melaporkan bahwa $C$. odorata telah menginvasi padang penggembalaan alam dan sudah mengurangi potensi ketersediaan pakan di Nusa Tenggara. Tanaman ini juga tidak dimakan ternak karena mengandung racun. Oleh karena itu, keberadaan $C$. odorata di padang penggembalaan perlu untuk dikendalikan. Pengendalian gulma secara manual merupakan cara pengendalian yang paling ramah lingkungan dan cocok dilakukan pada daerah yang ketersediaan tenaga kerjanya masih murah. Pembabatan atau pemotongan $C$. odorata sebaiknya dilakukan sebelum tanaman ini berbunga (Tjitrosoedirjo et al., 
1984). Pada suatu padang/kebun rumput untuk mendapatkan hasil yang optimal harus selalu dilakukan pemanenan dengan cara pemotongan atau penggembalaan sesuai dengan interval waktu tertentu. Interval pemotongan yang optimum akan mendapatkan produksi hijauan yang tinggi dan kualitas yang bagus. Melalui pemotongan ini selain untuk melakukan pemanenan juga diharapkan sekaligus sebagai cara untuk mengendalikan gulma.

Rumput Brachiaria humidicola merupakan hijauan yang palatabel, dan dapat juga digunakan sebagai rumput potongan dan rumput penggembalaan. Rumput ini mempunyai kemampuan untuk menekan pertumbuhan gulma, adaptif terhadap pengairan yang tidak begitu bagus, toleran terhadap penggembalaan berat dan membutuhkan kesuburan tanah rendah, sehingga mempunyai peranan yang cukup besar bagi pengembangan dan penyediaan hijauan di tropik ('tMannetje dan Jones, 1992).

Nilai produktif dari hijauan pakan tergantung pada kuantitas yang dimakan ternak dan selanjutnya hijauan yang dikonsumsi memenuhi kebutuhan energi, protein, mineral dan vitamin (Minson, 1990). Nilai produktif ini dapat dilihat dengan mengetahui kualitas nutrisi (komposisi kimia) dan kecernaan dari pakan tersebut. Kecernaan suatu hijauan mempunyai peranan yang sangat penting dalam menentukan nilai nutrisi. Beberapa studi yang telah dilakukan bahwa metode kimia kurang begitu tinggi korelasinya dengan metode in vivo pada pengukuran kualitas hijauan dibanding dengan metode enzimatis dan microbial (Barnes, 1973; Marten, 1981; van Soest,1994). Oleh karena itu untuk menentukan kualitas hijauan perlu dilanjutkan dengan metode in vitro atau in sacco (Van Soest, 1994). Metode in vitro mempunyai korelasi nilai yang sangat bagus dengan metode in vivo (Judkins et al., 1990) dan sampel yang diuji bisa lebih banyak dengan bahan sedikit dan tentunya tidak terlalu banyak memakan biaya. Selain untuk melihat kecernaan, metode in vitro dapat dilakukan untuk mengukur konsentrasi ammonia dan asam lemak terbang yang dihasilkan. Pada umumnya tanaman yang lebih muda akan mempunyai konsentrasi ammonia dan asam lemak terbang yang lebih tinggi dibanding pada tanaman yang lebih tua, karena tanaman yang muda mempunyai protein kasar dan karbohidrat yang tinggi.

Tujuan dari penelitian ini untuk melihat pengaruh inteval pemotongan rumput $B$. humidicola yang terinvasi $C$. odorata terhadap konsentrasi ammonia dan asam lemak terbang dari hijauan rumput $B$. humidicola yang dihasilkan secara in vitro.

\section{Materi dan Metode}

Penelitian dilakukan pada bulan Februari 2003 - Januari 2004 di Kebun Percobaan Laboratorium Agrostologi Fakultas Peternakan Institut Pertanian Bogor. Bahan tanaman yang digunakan adalah sobekan rumput - rumput $B$. humidicola dan bonggol untuk $C$. odorata. Rumput B. humidicola hasil penelitian, selanjutnya dianalisa kecernaan in vitro di Laboratorium Nutrisi Makanan Ternak Ruminansia dan Kimia Makanan Ternak Fakultas Peternakan Universitas Padjadjaran. Cairan rumen yang digunakan berasal dari cairan rumen Sapi Onggole. 
Penelitian terdiri dari sembilan metode penanaman dan pemotongan yang berbeda. Adapun perlakuan yang diberikan adalah sebagai berikut :

- Penanaman B. humidicola yang dipotong setiap 30 hari, dan tanpa penanaman $C$. odorata (p1);

- Penanaman B. humidicola yang dipotong setiap 60 hari, dan tanpa penanaman $C$. odorata (p2);

- Penanaman B. humidicola yang dipotong setiap 90 hari, dan tanpa penanaman $C$. odorata (p3);

- Penanaman B. humidicola dan $C$. odorata, rumput $B$. humidicola dipotong setiap 30 hari, dan $C$. odorata tidak dipotong (p4);

- Penanaman B. humidicola dan $C$. odorata, rumput $B$. humidicola dipotong setiap 60 hari, dan $C$. odorata tidak dipotong (p5);

- Penanaman B. humidicola dan $C$. odorata, rumput B. Humidicola dipotong setiap 90 hari, dan $C$. odorata tidak dipotong (p6);

- Penanaman B. humidicola dan $C$. odorata, serta keduanya dipotong setiap 30 hari (p7) ;

- Penanaman B. humidicola dan $C$. odorata, serta keduanya dipotong setiap 60 hari (p8) ;

- Penanaman B. humidicola dan $C$. odorata, serta keduanya dipotong setiap 90 hari (p9).

Ukuran satu unit percobaan adalah $3 \times 2 \mathrm{~m}$, yang dibatasi oleh parit dengan jarak 1 meter untuk kelompok dan 0,5 meter untuk perlakuan. Pemberian kapur sebanyak 9 ton per ha, pupuk kandang sebanyak 20 ton/ha, dan Urea 450 $\mathrm{kg} / \mathrm{ha}$, SP36 $150 \mathrm{~kg} / \mathrm{ha}$, dan KCL 430 $\mathrm{kg} / \mathrm{ha}$ sebagai pupuk dasar. Populasi C. odorata adalah 4 individu per $\mathrm{m}^{2}$ dengan jarak tanam 50 x $50 \mathrm{~cm}$. Jarak tanam $B$. humidicola adalah $30 \times 30$ $\mathrm{cm}$. Pemotongan penyeragaman (triming) dilakukan pada saat rumput $C$. odorata pada umur 4 bulan sesudah tanam sebagai awal penelitian. Pemotongan selanjutnya disesuaikan dengan perlakuan pemotongan. Peubah yang diukur pada penelitian ini meliputi konsentrasi ammonia dan asam lemak terbang dari hijauan rumput $B$. humidicola (in vitro). Pengukurannya dengan menggunakan metode in vitro dari Tilley dan Terry (1963). Rancangan yang digunakan adalah Rancangan petak Terbagi dalam Waktu. Waktu terdiri dari periode pemotongan pertama (t1) dan periode pemotongan terakhir (t2). Selanjutnya untuk mengetahui perbedaan setiap perlakuan dilakukan uji Jarak Berganda Duncan (Gasperz,1994).

\section{Hasil dan Pembahasan}

Konsentrasi Ammonia Cairan Rumen Sapi

Konsentrasi ammonia cairan rumen dari setiap perlakuan dapat dilihat pada Gambar 1. Hasil analisa ragam menunjukkan bahwa perlakuan berpengaruh sangat nyata pada konsentrasi ammonia dan terdapat interaksi antara perlakuan dengan periode pemotongan, sedangkan periode pemotongan tidak berpengaruh.

Pada interval pemotongan 30 hari (p1, p4 dan p7) konsentrasi ammonianya rendah dan meningkat pada interval pemotongan 60 hari (p2, p5, dan p8), setelah itu konsentrasinya turun lagi pada interval pemotongan 
90 hari (p3, p6 dan p9), kecuali pada pemotongan akhir dari perlakuan yang ada $C$. odorata (p7, p8 dan p9) ammonia menurun sejalan dengan me-ningkatnya interval pemotongan. Pola yang dibentuk tentunya merupakan suatu hal yang menarik. Hal ini disebabkan oleh faktor genetik dari tanaman tersebut dan pengaruh umur tanaman.

Tanaman B. humidicola pada awal pertumbuhannya mempunyai sifat akan berusaha menutup permukaan tanah yang belum tertutupi dengan cara perbanyakan stolon (pertumbuhan horizontal). Setelah stolon saling bertemu baru akan terjadi pertumbuhan vertikal. Pada saat melakukan penutupan lahan akan terdapat produksi batang (stolon) yang lebih banyak dibanding dengan daun. Tumbuhan ini mempunyai pertumbuhan stolon yang sangat tinggi ('tMenntje dan Jones, 1992; Skerman dan Riveros, 1990).
Secara umum batang mempunyai kandungan protein yang lebih rendah dibanding daun (Cheeke, 1999; Smith et al., 1980). Kandungan protein yang rendah akan menghasilkan konsentrasi ammonia cairan rumen yang rendah, karena ammonia merupakan produk utama katabolisme protein pakan (Wallace et al., 1997). Sehingga pada interval pemotongan 30 hari mempunyai konsentrasi asam ammonia yang lebih rendah.

Penurunan konsentrasi ammonia pada umur tua (90 hari) dikarenakan terjadi perubahan komposisi kimia pada hijauan. Pada tanaman tua terjadi penurunan kandungan protein, peningkatan kandungan karbohidrat struktural dengan lignin, penurunan karbohidrat tersedia dan penurunan dalam kecernaan protein dan energi (Chruch, 1991). Kandungan protein kasar dari hijauan akan mempengaruhi terhadap konsentrasi am-

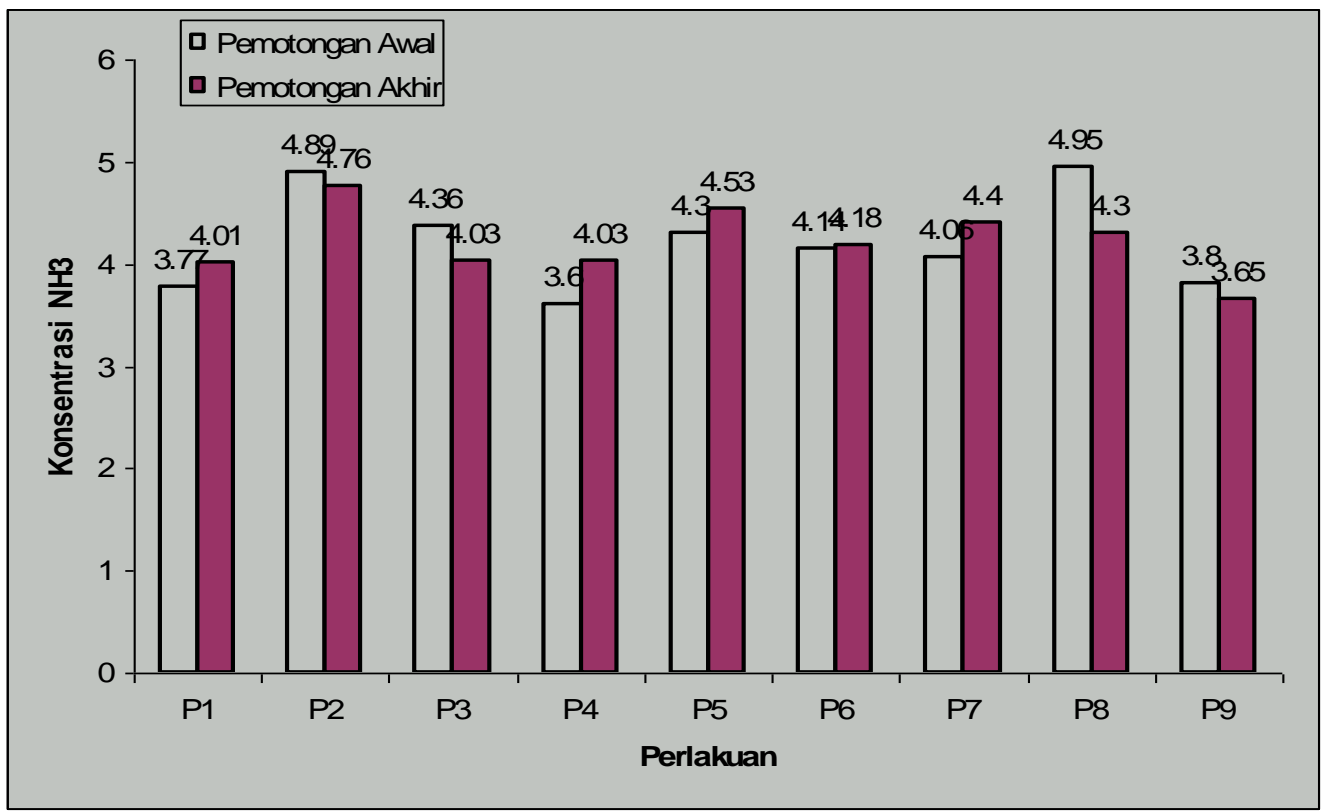

Gambar 1. Konsentrasi Ammonia Lemak Terbang Total Cairan Rumen 
monia. Kandungan protein kasar yang kurang dari $7 \%$ akan membuat aktivitas mikroba rumen tertekan karena kekurangan ammonia. Keadaan ini akan menurunkan pencernaan karbohidrat, dan mempengaruhi kandungan asam lemak terbang yang dihasilkan.

Adanya interaksi antara perlakuan dengan periode panen lebih disebabkan oleh dua faktor yang disebutkan di atas yaitu faktor tanaman itu sendiri (sifat pertumbuhan dari B. humidicola ) dan faktor elemen - elemen iklim di lokasi penelitian. Pada saat pemotongan awal (bulan Juli 2003), elemen elemen iklim di lokasi penelitian tidak begitu baik untuk mendukung pertumbuhan rumput secara optimal (BMG, 2004). Curah hujan yang kecil, penguapan yang tinggi dan penyinaran yang kuat akan membuat tanaman menjadi cepat tua dan mempercepat proses lignifikasi. Chowder dan Cheda (1982) menyatakan pada kondisi kelembaban tanah yang rendah dan intensitas penyinaran yang tinggi akan mendorong tanaman untuk cepat matang secara fisiologi dengan disertasi penurunan kandungan protein kasar dan pembentukan lignin yang tinggi.

Berdasarkan pada hasil analisis terlihat bahwa kehadiran dan pemotongan $C$. odorata tidak mempengaruhi nilai konsentrasi ammonia hijauan (in vitro). Dampak negatif dari pengaruh naungan maupun persaingan hara $C$. odorata tidak terlihat. Pada kondisi populasi $C$. odorata seperti pada penelitian tidak mempengaruhi pada konsentrasi ammonia hijauan rumput $B$. humidicola. Hal yang sama terjadi dengan produksi bahan kering, bahwa kehadiran dan pemotongan $C$. odorata tidak berpengaruh.
Konsentrasi Asam Lemak Terbang Cairan Rumen Sapi

Konsentrasi asam lemak terbang total cairan rumen dari setiap perlakuan dapat dilihat pada Gambar 2. Hasil analisis ragam menunjukkan bahwa perlakuan berpengaruh sangat nyata pada konsentrasi asam lemak terbang dan periode pemotongan tidak berpengaruh, serta tidak terdapat interaksi antara periode pemotongan dengan perlakuan terhadap konsentrasi asam lemak terbang.

Pola data dari konsentrasi asam lemak terbang yang dihasilkan membentuk pola yang sama dengan konsentrasi ammonia. Pada umumnya konsentrasi asam lemak terbang akan mempunyai konsentrasi yang lebih tinggi pada saat tanaman pakan yang diberikan masih muda, karena tanaman yang masih muda biasanya mempunyai kandungan nutrisi yang dapat dicerna lebih tinggi (Coleman dan Henry, 2002; Smith et al., 1986) dan konsentrasi asam lemak terbang yang dihasilkan tergantung pada kandungan nutrisi yang dipunyai oleh pakan (Perry, 1980). Pola tersebut terjadi disebabkan oleh pola pertumbuhan dari rumput $B$. humidicola itu sendiri. Penjelasan untuk pembahasan konsentrasi ammonia dapat digunakan juga untuk menjelaskan fenomena ini.

Selanjutnya akibat dari karakteristik dari tanaman ini mempengaruhi konsentrasi ammonia, makanya konsentrasi asam lemak terbang mempunyai mempunyai pola yang sama dengan konsentrasi ammonia. Keberadaan ammonia dalam cairan rumen merupakan kunci selanjutnya dalam degradasi pertumbuhan mikroba dan sintesa protein. Konsentrasi ammonia yang rendah akan menyebabkan pertumbuhan mikroba rumen menjadi rendah atau lambat. Kon- 


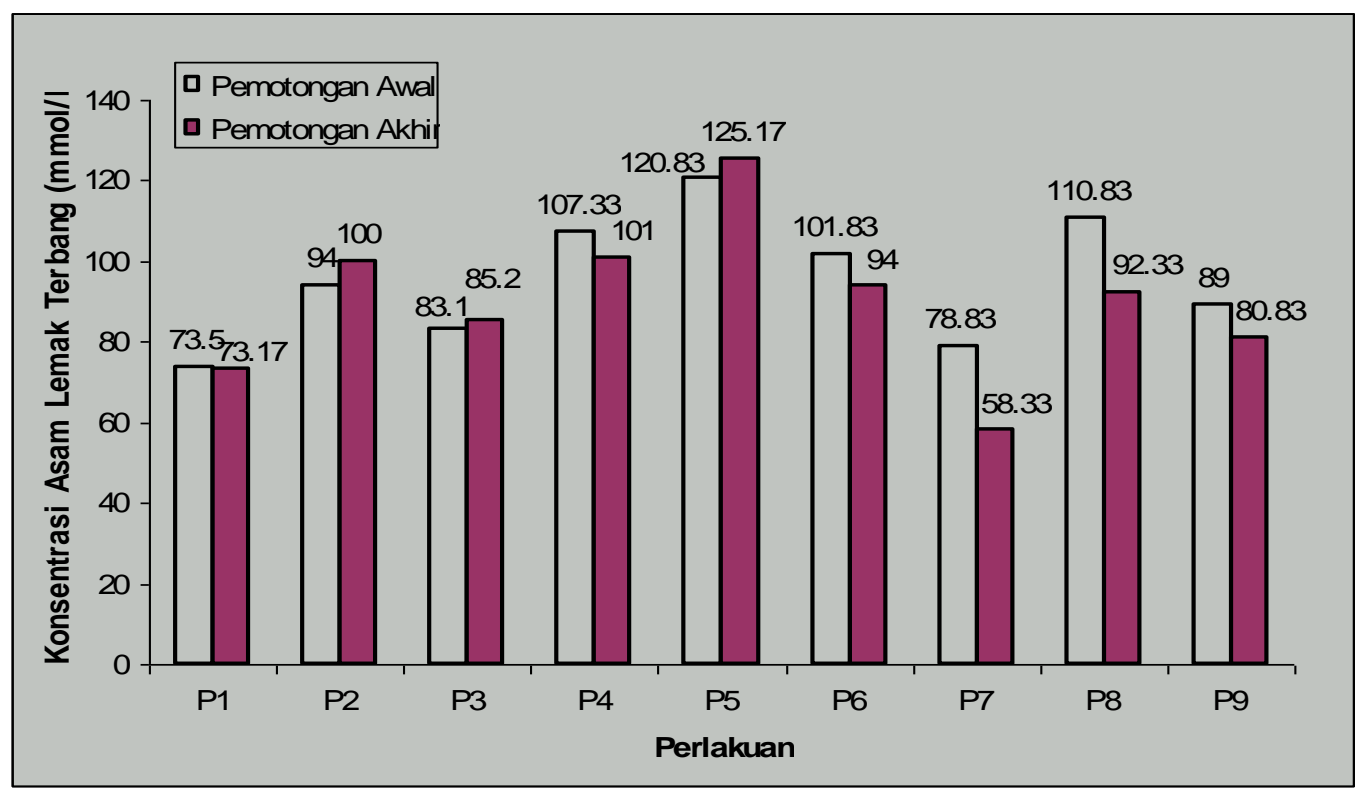

Gambar 2. Konsentrasi Asam Lemak Terbang Total Cairan Rumen

sekwensinya perombakan karbohidrat menjadi terbatas (Mc Donald et al., 2002), karena asam lemak terbang merupakan produk akhir dari fermentasi karbohidrat (Cheeke, 1999 ; Perry, 1980). Maka selanjutnya asam lemak terbang yang dihasilkan pun lebihrendah.

Sama seperti pada konsentrasi ammonia, kehadiran dan pemotongan $C$. odorata tidak mempengaruhi nilai konsentrasi asam lemak terbang hijauan. Dampak negatif dari pengaruh naungan maupun persaingan hara $C$. odorata tidak terlihat. Pada kondisi populasi $C$. odorata seperti pada penelitian tidak mempengaruhi pada konsentrasi asam lemak terbang hijauan.

\section{Kesimpulan}

1. Konsentrasi ammonia cairan rumen dan produksi ammonia dari hijauan rumput $B$. humidicola pada interval pemotongan 60 hari relatif lebih tinggi dari pada interval pemotongan 30 hari dan 90 hari.

2. Kehadiran dan pemotongan $C$. odorata tidak berpengaruh terhadap konsentrasi ammonia cairan rumen dan produksi dari rumput $B$. humidicola.

\section{Daftar Pustaka}

Badan Meteorologi dan Geofisika. 2004. Data Klimatologi Wilayah Darmaga. Balai Wilayah I. Stasiun Klimatologi Klas I. Darmaga.

Barnes, R.F. 1973. Chemistry and Biochemistry of Herbage. Academic Press. London. Pp 179 214.

Bumualim A, J. Nulik, R.C. Gutterdge. 1990. Usaha Perbaikan Pakan Ternak Sapi di Nusa Tenggara. Jurnal Litbang Pertanian, 12 (2) : $38-44$.

Cheeke, P.R. 1999. Applied Animal Nutrition ; Feed and Feeding. 
Upper Saddle River, New Jersey. Prentice Hall.

Chruch, D.C. 1991. Livestock Feeds and Feeding. $3^{\text {rd }}$ Editions. Prentice Hall International Inc. Englewood, New Jersey.

Coleman, S.W, and D.A. henry. 2002. Sheep Nutrition. CAB International Publishing. Wallingford. UK. Pp 1- 26.

Crowder, L.V. and H.R. Chheda. 1982. Tropical Grassland Husbandry. Longman Inc. London and New York.

Gaspersz, V. 1994. Metode Perancangan Percobaan. Bandung. PT Armico. 472.

Judkins. M.B., L.J. Krysl, R.K. Barton. 1990. Estimating of digestibility: A Comparison of Eleven Techniques Across Six different diets Fed rams. J. Anim. Sci. 68. 1405 - 1415.

'tMannetje, L., R.M. Jones. 1992. Prosea 4; Forage. PROSEA. Bogor.

Mansyur, S. Hadjosoewignyo, L. Abdullah. 2004. Respon Rumput B. humidicola (randle) Schweick terhadap Interval Pemotongan. Jurnal Ilmu Ternak. 4 (2):57- 61.

Marten, G.C. 1981. Chemical, In vitro and Nylon Bag Procedures

Alamat korespondensi: Mansur

Fakultas Peternakan Universitas Padjajaran, Bandung

Jl. Raya Bandung-Sumedang Km. 21

Email: mancuy@yahoo.com

Artikel diterima: 12 Maret 2004, disetujui: 12 Desember 2004 for Evaluating forage in USA. In jl. Wheeler and RD Mochrie (eds). Forage Evaluaton: concept and Technique. Griffen Press. Netley. South Australia. Pp. 39 - 55.

Mcdonald, P, R.A. Edwards, J.F.D. Greenhalg and CA Morgan,2002. Animal Nutrition, $6^{\text {th }}$ ed. London, Prentice Hall.

Minson D.J. 1990. Tropical Grasses. FAO Plant Production and Protection Series No. 23. FAO. Rome.

Perry TW., 1980. Beef Cattle Feeding and Nutrition. Academic Press Inc. San Diego.

Skerman, P.J. and Riveros F., 1990. Tropical Grasses. FAO Plant Production and Protection Series No. 23. FAO. Rome.

Tilley, JMA and RA. Terry 1963. A Two Stage Technique for in vitro Digestin of. Forage Crops. J. Bri. Grass. Soc 18. 108 - 111.

Tjirosoedirdjo S, I.H. Utomo, J. Wiroatmojo. 1984. Pengelolaan Gulma di Perkebunan. Jakarta . PT Gramedia.

Van Soest, P.J. 1994. Nutritional Ecology in Ruminant. Cornall University Press, Ithaca, New York. 